\title{
Thin-Membrane Solid-Acid Fuel Cell
}

\author{
Tetsuya Uda* and Sossina M. Haile ${ }^{*, z}$
}

Department of Materials Science, California Institute of Technology, Pasadena, California 91125, USA

Solid-acid fuel cells (SCFCs) utilize an anhydrous, nonpolymeric proton conducting electrolyte that can operate at slightly elevated temperatures. By supporting thin $\mathrm{CsH}_{2} \mathrm{PO}_{4}$ electrolyte membranes $(25-36 \mu \mathrm{m})$, on porous stainless steel gas-diffusion electrodes, SAFCs with peak power densities as high as $415 \mathrm{~mW} / \mathrm{cm}^{2}$ were obtained. Cells were operated at $\sim 240^{\circ} \mathrm{C}$ with humidified $\mathrm{H}_{2}$ supplied to the anode and humidified $\mathrm{O}_{2}$ supplied to the cathode. Despite the thinness of the membranes, the open-circuit voltages were high, 0.91-1.01 V. These results transform SAFCs from laboratory curiosities into highly competitive energy conversion devices.

(C) 2005 The Electrochemical Society. [DOI: 10.1149/1.1883874] All rights reserved.

Manuscript received October 27, 2004. Available electronically March 24, 2005.

Because of their potential to reduce the environmental impact and geopolitical consequences of the use of fossil fuels, fuel cells have emerged as attractive alternatives to combustion engines. In addition to high efficiency and low emissions, fuel cells are appealing for their modular and distributed nature, and zero noise pollution. They will furthermore play an essential role in any future hydrogen fuel economy. We have recently demonstrated the utility of a novel class of proton-conducting compounds in both $\mathrm{H}_{2} / \mathrm{O}_{2}$ and direct methanol fuel cells. ${ }^{1}$ Compounds within this family of socalled solid acids are entirely impermeable ${ }^{2}$ and do not rely on hydration for the charge transport process. ${ }^{3}$ The specific material employed, $\mathrm{CsH}_{2} \mathrm{PO}_{4}$, exhibits high conductivity $\left(\sim 10^{-2} \mathrm{~S} / \mathrm{cm}\right)$ upon heating to temperatures above the superprotonic transition at $230^{\circ} \mathrm{C}{ }^{4,5}$ While the results to date have proven the viability of solid acid fuel cells, the power outputs obtained, $49 \mathrm{~mW} / \mathrm{cm}^{2}$ (peak power) at $0.37 \mathrm{~V}$, are not yet competitive with polymer electrolyte membrane (PEM) or other fuel cells, $\sim 1 \mathrm{~W} / \mathrm{cm}^{2}$ or higher at $\sim 0.7 \mathrm{~V}$, depending on operating conditions. The key limitation to higher power output has been fabrication of fuel cells containing thin electrolyte membranes, for which ohmic losses are minimized. We show here that it is possible to obtain peak power densities of $415 \mathrm{~mW} / \mathrm{cm}^{2}$ (at $0.35 \mathrm{~V}$ ), an almost eightfold increase from the earlier results, from $\mathrm{CsH}_{2} \mathrm{PO}_{4}$ based fuel cells constructed with 25 $\mu \mathrm{m}$ thick electrolytes.

\section{Experimental}

Materials.-A mixture of $\mathrm{CsH}_{2} \mathrm{PO}_{4}$, naphthalene, Pt black, and Pt supported on carbon (50 mass \% Pt) was used to form both the anode and cathode electrocatalysts. The ratio of the respective components was 3:0.5:3:1 (by mass), and the total Pt loading $7.7 \mathrm{mg} / \mathrm{cm}^{2}$ per electrode. Pt black (AlfaAesar, no.12755, HiSPEC1000, surface area: $27 \mathrm{~m}^{2} / \mathrm{g}$ ) and platinum supported on carbon (AlfaAesar, no.43989, HiSPEC8000) were used as received. $\mathrm{CsH}_{2} \mathrm{PO}_{4}$, used both in the electrocatalyst and electrolyte layers, was synthesized by methanol-induced precipitation from aqueous solutions of stoichiometric quantities of $\mathrm{CsCO}_{3}$ and $\mathrm{H}_{3} \mathrm{PO}_{4}$. Porous stainless steel, with average pore size and porosity of $40 \mu \mathrm{m}$ and $42-44 \%$, respectively, served as a current collector/gas-diffusion electrode and also served to provide mechanical support for the thin membrane structure.

Cell fabrication.-Fuel cells were fabricated by slurry deposition using toluene as a suspension medium. An electrocatalyst layer, an electrolyte layer, and a second gas diffusion layer with electrocatalyst layer were sequentially deposited onto a stainless steel gasdiffusion electrode. After deposition of each layer, the structure was uniaxially pressed to promote adhesion between layers, forming the final layer of the sandwiched structure, shown in Fig. 1. The electrolyte thickness was calculated from the weight of $\mathrm{CsH}_{2} \mathrm{PO}_{4}$ incor-

* Electrochemical Society Active Member
${ }^{\text {z }}$ E-mail: smhaile@caltech.edu porated into the electrolyte, and ranged from 25 to $36 \mu \mathrm{m}$. Prior to fuel cell characterization, the naphthalene was removed under gentle heating $\left(24 \mathrm{~h}\right.$ at $60^{\circ} \mathrm{C}$ in vacuum, $6 \mathrm{~h}$ at $160^{\circ} \mathrm{C}$ in argon gas, followed by a $2^{\circ} \mathrm{C} / \mathrm{min}$ ramp to $218^{\circ} \mathrm{C}$, the boiling point of naphthalene), leaving behind open porosity in the electrocatalyst layers.

Fuel cell measurement.-Polarization curves were collected from samples placed in an in-house constructed fuel cell measurement station using a Keithley 2420 source meter. Due to instrumental limitations, the maximum total current applied was $3 \mathrm{~A}$. Humidification was achieved by passing oxygen and hydrogen through water held at $72^{\circ} \mathrm{C}$, to obtain the desired water partial pressure of 0.3 atm. A total pressure of $1 \mathrm{~atm}$ was maintained at both electrodes, and the flow rates of hydrogen and oxygen fixed were at $200 \mathrm{sccm}$. Four independent fuel cell measurements were carried out. The cell temperature was maintained at $240^{\circ} \mathrm{C}$ (except run $\mathrm{A}, 248^{\circ} \mathrm{C}$ ). In run $\mathrm{C}$, a platinum-ruthenium alloy ( $\mathrm{Pt}: \mathrm{Ru}=50: 50 \mathrm{~mol}$ ratio, AlfaAesar, no. 41171, HiSPEC6000) and platinum (40 mass \%)-ruthenium (20 mass \%) supported on carbon (AlfaAesar, no. 44172, FCA-8X) were used as the anode electrocatalysts instead of platinum black and $\mathrm{Pt}$ supported on carbon, respectively. Outside of these exceptions, the cell materials and fabrication method were identical.

\section{Results}

The fuel cell polarization and power output curves of the four independent experiments are shown in Fig. 2. The characteristics of each cell are summarized in Table I. Despite the thinness of the membranes, from 25 to $36 \mu \mathrm{m}$, the open-circuit voltage (OCV) was high, with an average of $0.96 \mathrm{~V}$ and reaching $1.01 \mathrm{~V}$ in the case of run $\mathrm{B}(35 \mu \mathrm{m}$ thick electrolyte). These values are close to, but nonetheless lower than, the theoretical OCV of $1.15 \mathrm{~V}$ expected under the experimental conditions employed. The difference between the measured and theoretical voltage values are taken to be due to physical leakage of hydrogen gas to the cathode (or oxygen to the anode) rather than the appearance of electronic conduction to the electrolyte. Given the nature of the chemical bonding in $\mathrm{CsH}_{2} \mathrm{PO}_{4}$, electronic conductivity is unlikely. In addition, direct electromotive force measurements of the related material $\mathrm{CsHSO}_{4}$ show this class of materials to have proton transport numbers close to unity. ${ }^{6}$ The peak power densities ranged from 287 to $415 \mathrm{~mW} / \mathrm{cm}^{2}$. This latter

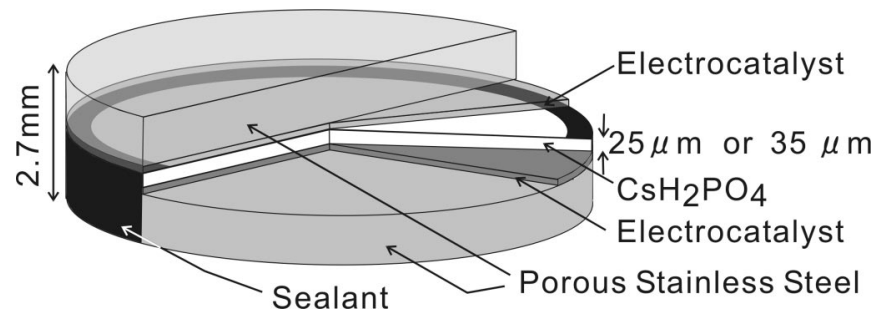

Figure 1. Schematic diagram of a fabricated cell. 

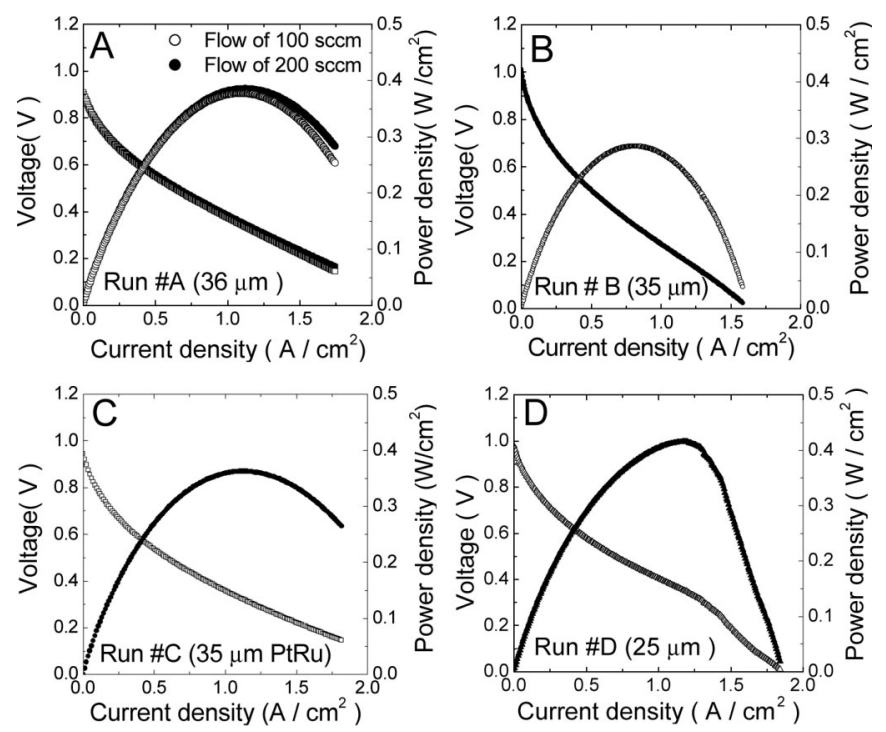

Figure 2. Cell voltage and power density curve obtained from four independent experiments. (A) Thickness $36 \mu \mathrm{m}, 100$, and $200 \mathrm{sccm}$; (B) thickness 35 $\mu \mathrm{m}$; (C) thickness $35 \mu \mathrm{m}$, PtRu catalyst for anode; (D) thickness $25 \mu \mathrm{m}$.

value, obtained from run D ( $25 \mu \mathrm{m}$ thick electrolyte), is highly competitive with state-of-the-art fuel cells, indeed, exceeding the values obtained from well-developed phosphoric acid fuel cells.

While these results are promising, two challenges for implementing $\mathrm{CsH}_{2} \mathrm{PO}_{4}$ in fuel cells emerged over the course of this work: poor mechanical integrity of the electrolyte and substantial overpotentials at the electrodes. In an earlier work, we demonstrated $100 \mathrm{~h}$ of stable operation of a $\mathrm{CsH}_{2} \mathrm{PO}_{4}$ based fuel cell constructed with a relatively thick, $260 \mu \mathrm{m}$, membrane. ${ }^{1}$ However, in the thin membranes implemented here, stable performance could not be achieved. For example, in Run C ( $35 \mu \mathrm{m}$ thick membrane) the OCV dropped from $0.95 \mathrm{~V}$ to $0.78 \mathrm{~V}$ within $2 \mathrm{~h}$ of the transition to the superprotonic phase $\left(230^{\circ} \mathrm{C}\right)$. In run $\mathrm{D}$, comprising a $25 \mu \mathrm{m}$ thick membrane, the polarization curve exhibits an unusual drop in voltage at high current density and loss of performance is evident already during this first polarization measurement. Subsequent to this measurement, the OCV did not return to its previous value. We presume that the loss in voltage across thin membranes results from the generation of physical leaks through the material itself. It is known that superprotonic solid acids exhibit superplastic behavior ${ }^{8}$ such that the material is easily deformed by even a slight mechanical force. Because superprotonic conductivity and superplastic mechancial properties result from the same chemical features of solid acids (rapid reorientation of tetrahedral oxyanion groups), designing materials that exhibit high proton conductivity without the tendency to undergo plastic flow may not be possible. Instead, designing a fuel cell structure that minimizes the mechanical pressure on the solid acid electrolyte may prove a more viable solution.

The typical sources of voltage drop in a fuel cell are slow electrocatalysis rates, slow ion transport across the electrolyte, and slow mass diffusion through the electrodes. From a comparison of results obtained at two different flow rates, Fig. 2A, it is evident that mass diffusion is not rate limiting under the present experimental conditions, even at the highest current densities. That is, operation of a fuel cell with gas flow rates of 100 and $200 \mathrm{sccm}$ resulted in essentially identical polarization curves and thus mass diffusion does not contribute to the voltage drop significantly. Of the remaining sources of voltage drop, the electrolyte contribution is also estimated to be very small. Taking the conductivity of $\mathrm{CsH}_{2} \mathrm{PO}_{4}$ to be 2.2

\begin{tabular}{|c|c|c|c|c|c|c|}
\hline \multirow[b]{2}{*}{$\begin{array}{l}\text { Run } \\
\text { no. }\end{array}$} & \multirow[b]{2}{*}{ Thickness } & \multirow[b]{2}{*}{$\begin{array}{l}\text { OCV } \\
(\mathrm{V})\end{array}$} & \multirow{2}{*}{$\begin{array}{c}\text { Peak } \\
\text { power } \\
\text { density } \\
\left(\mathrm{mW} / \mathrm{cm}^{2}\right)\end{array}$} & \multicolumn{3}{|c|}{ Voltage (V) } \\
\hline & & & & $\begin{array}{c}200 \\
\mathrm{~mA} / \mathrm{cm}^{2}\end{array}$ & $\begin{array}{c}400 \\
\mathrm{~mA} / \mathrm{cm}^{2}\end{array}$ & $\begin{array}{c}1000 \\
\mathrm{~mA} / \mathrm{cm}^{2}\end{array}$ \\
\hline A & $36(\mu \mathrm{m})$ & 0.91 & 385 & 0.70 & 0.60 & 0.38 \\
\hline B & $35(\mu \mathrm{m})$ & 1.01 & 287 & 0.70 & 0.56 & 0.27 \\
\hline $\mathrm{C}^{\mathrm{a}}$ & $35(\mu \mathrm{m})$ & 0.95 & 362 & 0.71 & 0.58 & 0.36 \\
\hline D & $25(\mu \mathrm{m})$ & 0.98 & 415 & 0.75 & 0.63 & 0.40 \\
\hline
\end{tabular}

${ }^{a}$ Platinum-ruthenium alloy was used for the anode catalyst in this run. The experiment was performed in connection with direct methanol fuel cell measurements to be reported separately, and the hydrogenoxygen results are presented here to demonstrate the reproducibility of the results of run $\mathrm{A}$.

$\times 10^{-2} \mathrm{~S} / \mathrm{cm}$ at $240^{\circ} \mathrm{C},{ }^{9}$ the area specific resistances of 25 and 35 $\mu \mathrm{m}$ thick membranes are 0.11 and $0.16 \Omega / \mathrm{cm}^{2}$, respectively. Thus, the voltage drop across these electrolytes at a current density of $1 \mathrm{~A} / \mathrm{cm}^{2}$ should be 0.11 and $0.16 \mathrm{~V}$, respectively. However, the measured voltage drop was significantly higher, $0.53-0.74 \mathrm{~V}$ at a current density of $1 \mathrm{~A} / \mathrm{cm}^{2}$ for both thickness, Table I. Thus, as much as $81 \%$ of the loss in voltage is due to slow electrocatalysis rates (run D). Moreover, the performance of Pt electrodes was found to be somewhat erratic (run A vs. run B) whereas PtRu as an anode electrocatalyst resulted in a cell with overall electrode performance equal to that of the best of the Pt only cells. Accordingly, further increases in power densities for solid acid fuel cells will require enhancements in electrocatalytic activity, more so than continued reductions in electrolyte thickness. At this stage, little effort has been directed toward enhancing electrocatalysis rates via optimization of catalyst structure and/or chemistry, suggesting that major improvements are possible.

In summary, it is possible to fabricate thin-film membrane fuel cells using $\mathrm{CsH}_{2} \mathrm{PO}_{4}$ as the electrolyte and obtain competitive power outputs. Further major increases in power density will require improvements in the electrocatalysis rates at the electrodes. In addition, mechanical stabilization of the electrolyte will be essential for sustained long-term performance. The many advantages of warmtemperature anhydrous proton conductors over polymeric electrolytes encourage efforts to address these challenges.

\section{Acknowledgments}

Funding for this work has been provided by the National Science Foundation, Division of Materials Research, and the Office of Naval Research, Office of Electrochemical Power Science and Technology. The authors thank Dr. D. A. Boysen and Dr. C. R. I. Chisholm for useful discussions.

The California Institute of Technology assisted in meeting the publication costs of this article.

\section{References}

1. D. A. Boysen, T. Uda, C. R. I. Chisholm, and S. M. Haile, Science, 303, 68 (2004), 2. S. M. Haile, D. A. Boysen C. R. I. Chisholm, and R. B. Merle, Nature (London), 410, 910 (2001).

3. T. Norby, Nature (London), 410, 877 (2001).

4. J. Otomo, N. Minagawa, C. Wen, K. Eguchi, and H. Takahashi, Solid State Ionics, 156, 357 (2003).

5. D. A. Boysen, S. M. Haile, H. Liu, and R. A. Secco, Chem. Mater, 15, 727 (2003).

6. T. Uda, D. A. Boysen, and S. M. Haile, Solid State Ionics, 176, 127 (2005).

7. Fuel Cell Handbook, p. 6, U.S. Department of Energy, Office of Fossil Energy, Washington, DC (2000).

8. L. F. Kirpichnikova, A. A. Urusovkaya, and V. I. Mozgovoc, JETP Lett., 62, 638 (1995).

9. C. R. I. Chisholm and S. M. Haile, Unpublished results. 